\section{Soviet writers protest successfully about environment science}

\section{London}

THE campaign to avert the southward diversion of the Siberian rivers has not yet been won, a leading Soviet author, Sergei Zalygin, has warned his fellow writers. Addressing a plenary board meeting of the Union of Writers of the USSR, he warned that the decree halting work on the diversion had authorized "further study" of the problems involved. "And so, if in the past a design organization received money for the project, now it will aim to get it for both the project and the problem", he said.

Zalygin is a member of the group of Russian writers known as the "villagers", which is widely credited with a decisive role in halting the diversion. Although the role of the villagers has been tactily denied by Academician Aleksandr Yanshin, a leading geographer, who has publicly stated that the cancellation was based solely on "expert opinion", Zalygin and his colleagues have come under attack from the hydrotechnical establishment.

It is not merely a matter of redeploying those who worked on the project $-6,000$ specialists in just one "institute for diversion" - Zalygin said. Some of these engineers and designers had lived with the project all their working lives and had received medals, prizes and titles of honour for their efforts. The psychological effect of being told that all this work was "to no purpose" was considerable.

The writers expressed concern about the drying up of the Aral Sea, the Daugavpils hydroelectric scheme in Latvia, and the Kara-Bogaz-Gol dam all cases where central planning has paid insufficient attention to local consequences. The Aral Sea has been depleted by over-use of its feeder rivers for irrigation (a situation that the diversion project was intended to rectify), the damming off of the Kara-Bogaz-Gol bay from the Caspian to reduce evaporation losses of the latter destroyed the brine feedstocks of the chemical industry of Turkmenia,

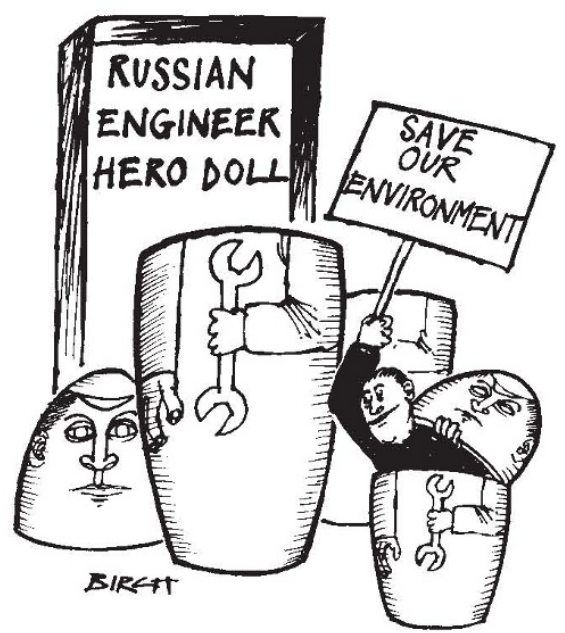

and the Daugavpils hydroelectric scheme is viewed as a threat to the environment and population of Latvia and Byelorussia. All these controversies could be interpreted as a protest by the non-Russian republics against Moscow; hence the speakers at the writers' meeting were careful to stress that in taking up the ecological needs of their republics, they relied on the example and support of their Russian colleagues.

In spite of what Zalygin sees as the

\title{
United Kingdom to process in parallel
}

\section{London}

BrITISH public agencies have announced a £3.5-million programme to encourage the use of the microchips called transputers in novel products. The programme is being supported by the Science and Engineering Research Council (SERC) and by the Department of Trade and Industry.

Transputers are the most recent microchips produced by the design and manufacturing company Inmos, founded with financial help from the British government but now a subsidiary of Thorn-EMI, the British consumer products manufacturer and defence contractor. The devices, which concentrate memory, processing capacity and communications channels in a single silicon chip, are reckoned to be especially promising as components in the design of parallel processing computers.

Inmos is supported by others in its belief that its transputers are at present more advanced than comparable devices manufactured elsewhere, but there is anxiety that the present advantages are being eroded by developments in the United States and Japan.

This point was put forcefully to SERC, at the end of last year, by its Engineering Board's computer facilities committee, which argued that the market for hardware for parallel processing could amount to several hundreds of millions of pounds a year, but that effort was needed to ensure a fair share for transputers.

The new programme will be coordinated from SERC's Rutherford-Appleton Laboratory and will seek both to promote the use of the device in products now being developed and to tap academic expertise in the development of software for use with transputers.

\section{Anger over nuclear waste plans}

London

Official British government advisers on nuclear waste disposal are angry because they were not consulted over the government's recent decision to abandon four potential trench disposal sites, and have demanded a meeting with the Secretary of State for the Environment to discuss the issue. The acting chairman of the Radioactive Waste Management Advisory Committee (RAWMAC), Professor John Greening, has warned the British public not to be misled into thinking there is independent assessment of the government's nuclear-waste disposal policies. The committee, appointed by the Secretary of State for the Environment to offer independent advice, first heard of the decision through the media and has still not been given enough information for the proper assessment of the change in nuclear waste disposal plans.

"There is a fair degree of annoyance" among committee members over the way the decision was made, Greening says. "We're puzzled that after all the research we had done we were not consulted." He suggests there was "some political advantage" in the decision.

RAWMAC is still concerned about whether the Drigg repository can handle all the low-level waste produced in Britain before an alternative deep repository site is developed. "Some calculations of committee members don't coincide with those from NIREX [the Nuclear Industry Radioactive Waste Executive]. The Drigg site may fill up faster than they think", Greening says. Kathy Johnston

vested interests of the engineers, glasnost is producing high-level measures on environmental issues. During the past few weeks, government and party resolutions have been passed on the protection of Lake Baikal, and a number of high officials have been censured, dismissed or allowed to take early retirement for slackness in implementing previous legislation. Similar measures have been taken to step up protection of Lake Ladoga (which, like Lake Baikal, is under considerable threat from the cellulose and the paper industries).

Last week a "public committee" for the Aral Sea and a "Soviet Greenpeace" were established under Zalygin's chairmanship, as a commission of the Soviet Peace Committee "to combine the anti-war struggle with environmental protection". And the Minister of Forestry of the Turkmen SSR has been dismissed for "inertia" in protecting the nature reserves and national parks under his jurisdiction the highest official, so far, to be ousted on environmental grounds.
Vera Rich 